\title{
PEMBELAJARAN MATEMATIKA KONTEKSTUAL KELOMPOK PERMANEN DAN TIDAK PERMANEN DALAM MENINGKATKAN KEMAMPUAN PENALARAN DAN KOMUNIKASI MATEMATIK SISWA SEKOLAH DASAR
}

\author{
Husen Windayana
}

\begin{abstract}
ABSTRAK
Penelitian ini mengkaji tentang kemampuan penalaran, komunikasi matematik dan sikap siswa dengan pembelajaran kontekstual melalui belajar kelompok permanen dan kelompok tidak permanen, kemudian dilihat pengaruhnya terhadap kemampuan penalaran, komunikasi matematik, dan sikap siswa. Penelitian ini menggunakan disain kuasi eksperimen kelompok kontrol pretes-postes. Kelompok pertama adalah kelas eksperimen yang terdiri dari dua pasang kumpulan siswa yang masing-masing memperoleh pembelajaran matematika kontekstual kelompok permanen dan pembelajaran matematika kontekstual kelompok tidak permanen menurut katagori sekolah sedang dan rendah. Sedangkan kelompok kontrol adalah siswa yang memperoleh pembelajaran matematika biasa menurut katagori sekolah sedang dan rendah. Populasi penelitian ini adalah seluruh siswa sekolah dasar kelas empat di wilayah Kabupaten Bandung, dan pemilihan sampel secara purposif menurut sekolah dan secara acak menurut kelas.

Hasil penelitian menunjukkan secara signifikan pada tingkat kepercayaan 0,05 bahwa kemampuan penalaran, komunikasi matematik, dan sikap siswa dalam pembelajaran matematika kontekstual kelompok permanen (PMKKP) dan kelompok tidak permanen (PMKKTP) lebih baik dari pembelajaran matematika biasa dalam katagori sekolah sedang dan rendah. Namun kemampuan penalaran, komunikasi matematik, dan sikap siswa pada pembelajaran matematika kontekstual kelompok permanen (PMKKP) dan kelompok tidak permanen (PMKKTP) tidak berbeda secara signifikan dalam katagori sekolah sedang dan rendah. Terjadi interaksi antara model pembelajaran dengan katagori sekolah terhadap kemampuan komunikasi matematik dan sikap siswa. Untuk kemampuan komunikasi matematik dan sikap siswa model pembelajaran matematika kontekstual kelompok permanen (PMKKP) baik untuk katagori sekolah sedang dan pembelajaran matematika kontekstual kelompok tidak permanen (PMKKTP) baik untuk katagori sekolah rendah.
\end{abstract}

Kata Kunci: Pembelajaran Matematika Kontekstual, Kelompok Permanen, Kelompok Tidak Permanen, Penalaran, Komunikasi Matematik. 


\section{A. Pendahuluan}

Era global membuat setiap bangsa dalam sebuah negara tidak lagi terbatasi oleh sekat-sekat wilayah, sehingga informasi dari negara luar dapat dengan cepat masuk ke tatanan masyarakat dan menciptakan tantangan serta persaingan dalam kehidupan. Hanya bangsa dengan sumber daya manusia yang unggul yang akan memenangkan persaingan dan mengatasi tantangan tersebut.

Pembentukkan sumber daya manusia yang unggul hanya mungkin dilakukan oleh pendidikan. Sementara kualitas pendidikan kita dewasa ini masih belum memuaskan, banyak hasil studi misalnya TIMSS (1999) melaporkan bahwa kemampuan matematika siswa kita dari 38 negara peserta masih ada di level bawah. Wahyudin (2005), Zulkardi (2001) dan Marpaung (2001) senada mengatakan bahwa dilihat dari nilai prestasi belajar, kemampuan matematika siswa kita masih rendah, meskipun ada beberapa siswa yang memiliki prestasi sangat baik.

Rendahnya hasil belajar matematika siswa, antara lain adalah rendahnya kualitas proses belajar matematika sekolah kita. Fauzan (2002) mengemukakan bahwa banyak siswa Sekolah Menengah Atas yang tidak tahu tentang objek geometri seperti persegi, persegipanjang, dan segitiga sama sisi. Lebih jauh beberapa mahasiswa tidak dapat memecahkan soal sederhana seperti $1 / 3+1 / 4$ dan -2 - 3 setelah mereka mempelajarinya beberapa tahun silam. Keadaan demikian mungkin disebabkan oleh rendahnya kualitas proses belajar mengajar di tingkat sekolah dasar yang berpengaruh terhadap pemahaman di tingkat selanjutnya. Dugaan ini dibenarkan oleh Soedjadi (Fauzan, 2002) bahwa, kualitas pendidikan matematika di sekolah dasar dan sekolah menengah pertama masih rendah. Rendahnya mutu pendidikan matematika tersebut tidak hanya dicerminkan oleh hasil belajar siswa yang rendah, tetapi juga oleh rendahnya kualitas proses belajar mengajarnya.

Perubahan kurikulum yang dilakukan pemerintah hampir setiap sepuluh tahun sekali belum mampu meningkatkan kualitas proses dan hasil belajar siswa. Salah satunya disebabkan karena suasana belajar di kelas tidak pernah berubah, sekalipun kurikulum terus berubah. Iklim belajar matematika di kelas masih 
seputar menggunakan metoda konvensional atau mekanistik yang menekankan kepada penguasaan prosedur atau algoritma penyelesaian soal dan mengabaikan penguasaan konsep. Seperti Mullis dkk. (2000) melaporkan bahwa umumnya pembelajaran matematika di kelas masih terpusat pada pengembangan keterampilan prosedural berupa pembentukkan keterampilan menyelesaikan soalsoal, belum terfokus pada pengembangan nalar siswa. Siswa belajar matematika adalah belajar bagaimana menyelesaikan soal bukan belajar mengapa soal tersebut diselesaikan seperti itu. Seperti juga sering dikemukakan oleh para pemerhati maupun para peneliti pendidikan matematika bahwa proses belajar mengajar matematika saat ini umumnya menggunakan cara-cara langsung, dimana guru langsung menjelaskan konsep pada siswa, atau siswa menerima konsep yang telah jadi dari guru, siswa tidak diberi kesempaan untuk melakukan eksplorasi misalnya.

National Council of Teacher of Mathematics (NCTM) merekomendasi bahwa terpahaminya konsep ketika siswa belajar matematika harus merupakan prioritas para pendidik, sehingga dengan demikian guru didorong untuk mencari dan menemukan alternatif-alternatif pembelajaran yang memungkinkan siswa mampu memahami dan mempelajari konsep-konsep matematika secara baik. Beberapa peneliti misalnya Confrey (1994) dan Labinowiez (1985) mempunyai pandangan sama terhadap kemudahan siswa dalam memahami konsep matematika. Lebih lanjut mereka mengatakan bahwa siswa akan mudah memahami konsep yang dipelajarinya apabila belajarnya menggunakan falsafah belajar konstruktivistik, yaitu suatu pandangan belajar mengajar yang memberi kesempatan siswa mengkonstruk pengetahuan melalui interaksi dengan lingkungan. Melalui persoalan-persoalan yang dikenal atau dipahaminya (contextual problem), siswa aktif memahami konsep-konsep matematika dan siswa membangun pengetahuan-pengetahuan matematik. Pandangan ini memungkinkan siswa memahami konsep-konsep matematika melalui berbagai strategi berpikir yang beragam sesuai dengan cara dan kemampuan masingmasing siswa. 
Contextual problem adalah instrumen dalam upaya menciptakan konflik kognitif yang bermanfaat dalam membangun pemahaman. Seperti dikatakan Piaget (1980) bahwa situasi kontradiksi yang berimplikasi terhadap terciptanya konflik kognitif adalah salah satu cara efektif dalam membangun pemahaman. Dengan kata lain contextual problem dalam pembelajaran matematika kontekstual adalah salah satu cara yang dapat membantu siswa lebih mudah memahami konsep-konsep matematika ketika belajar. Di samping itu dengan masalah kontekstual siswa akan merasa lebih tertarik dalam belajar. Seperti dikemukakan Zulkardi (Hadi, 2006) bahwa siswa akan lebih tertarik belajar matematika ketika guru menghadirkan masalah kontekstual dan realistik.

Pembelajaran kontekstual yang didasarkan atas falsafah belajar konstruktivistik adalah pendekatan belajar mengajar dengan memanfaatkan masalah atau situasi yang dipahami siswa dalam upaya siswa membangun pemahaman. Melalui masalah-masalah kontekstual siswa membangun pengertian atau pemahaman dengan memberdayakan pengetahuan dan pengalaman yang ada dalam diri siswa itu sendiri. Pengetahuan baru siswa adalah hasil konstruksi yang dibangun dari pengalaman dan pengetahuan hasil interaksi dirinya dengan lingkungan. Belajar melalui masalah-masalah kontekstual membuka peluang siswa membuat kaitan antara realitas dengan dunia abstraks berupa konsep-konsep matematika. Seperti dikatakan Zulkardi (Hadi, 2006) bahwa, pembelajaran matematika akan lebih menarik dan bermakna bagi siswa apabila guru menghadirkan masalah kontekstual dan realistik, yaitu masalah yang dikenal dan dekat dengan kehidupan sehari-hari siswa.

Uraian di atas memberi gambaran bahwa pembelajaran matematika kontekstual dapat memfasilitasi belajar siswa ke arah yang lebih mudah dipahami dan lebih bermakna. Pembelajaran matematika kontekstual dapat melayani semua kelompok siswa dalam belajar, baik siswa pandai, siswa sedang, maupun siswa kurang. Hal itu dikarenakan pembelajaran matematika kontekstual dapat melayani semua tingkat kemampuan siswa, dikarenakan melalui pembelajaran matematika kontekstual siswa belajar dari situasi yang kontekstual baginya atau pengalamannya sendiri yang kemudian diarahkan menuju pembentukan 
pemahaman konsep matematika. Sehingga melalui pembelajaran matematika kontekstual konsep-konsep matematika yang abstrak dibangun dari situasi konkrit dunia nyata, dan memungkinkan konsep-konsep itu mudah terpahami untuk dikembangkan dan akan lebih bermakna bagi siswa.

Pembelajaran matematika yang menggunakan masalah kontekstual memungkinkan siswa belajar atau bekerja bersama-sama. Melalui masalah konteks siswa bekerja sama untuk merencanakan strategi pemecahan. Bentuk kerja sama yang paling memungkinkan adalah setting belajar kelompok (cooperative learning). Melalui belajar kelompok siswa memikirkan bentukbentuk representasi model yang cocok hasil menerjemahkan masalah yang diberikan. Sembiring (2006) mengemukakan bahwa, banyak keuntungan yang dapat diperoleh siswa melalui belajar kelompok, misalnya bentuk soal cerita yang kontekstual diselesaikan siswa melalui bekerja dalam kelompok, siswa saling berdiskusi, berinisiatif dan kreatif menemukan alternatif pemecahan. Berdiskusi, saling menghargai pendapat teman, dan mengambil keputusan hasil diskusi.

Upaya untuk menciptakan situasi belajar mengajar yang aktif dapat dilakukan dalam belajar kelompok. Belajar kelompok (Cooperative Learning) salah satu cara belajar untuk mencapai tujuan-tujuan pembelajaran melalui usaha kerja sama, saling membantu, berbagi ide, bertukar pengalaman dalam menyelesaikan tugas. Dalam kelompok siswa berdiskusi, berlatih mengemukakan ide dan gagasan ketika memecahkan pemasalahan dan belajar mengambil kesimpulan. Kemampuan tersebut menjadi sangat penting untuk menyikapi suasana kehidupan di masa yang akan datang.

Di sisi lain, Kurikulum Matematika Sekolah Dasar Tahun 2006 memuat beberapa kemampuan yang harus terbentuk dalam diri siswa sebagai hasil belajar matematika, dua diantaranya adalah kemampuan penalaran dan komunikasi matematik. Penalaran dalam matematika merupakan sesuatu yang pokok dan penting, tidak pernah sedikitpun penalaran lepas dari matematika, sehingga dapat dikatakan bahwa penalaran adalah intinya matematika. Setiap belajar matematika pasti berkenaan dengan penalaran, oleh karenanya kemampuan penalaran akan menggambarkan kemampuan matematiknya. Begitu pula komunikasi matematik 
adalah hal lain yang juga tidak dapat dipisahkan dari penalaran dan matematika. Matematika adalah komunikasi dalam bentuk bahasa tulisan dan lisan yang untuk memahaminya diperlukan kemampuan penalaran. Semua orang sepakat bahwa matematika adalah bahasa simbol, dan simbol-simbol matematika tersebut sebagai media atau alat untuk berkomunikasi secara matematik. Kemampuan penalaran dan komunikasi matematik siswa sekolah dasar saat ini belum menunjukkan keadaan yang memuaskan. Masih banyak didapati siswa sekolah dasar yang cara bernalarnya rancu dan tidak berdasar. Misalnya dalam menjumlahkan dua bilangan dua angka dengan cara bersusun ke bawah, umumnya yang siswa lakukan adalah, menulis angka-angka tersebut secara tersusun dimana angka satuan sejajar dengan angka satuan dan angka puluhan sejajar dengan angka puluhan. Kemudian dijumlahkan satuan dengan satuan, puluhan dengan puluhan. Apabila menulisnya tidak tersusun seperti itu siswa tidak dapat melakukan penjumlahan tersebut secara benar. Sehingga yang dipahami siswa adalah cara/algoritma menjumlah, bukan alasan logis yang mendasari mengapa muncul aturan/algoritma seperti itu. Ilustrasi seperti di atas sering dijumpai, dan hal tersebut adalah sebuah contoh pembelajaran matematika yang mengabaikan penalaran, dimana penalaran adalah sesuatu yang esensial. Begitu pula dengan rendahnya kemampuan siswa pada komunikasi matematik, masih banyak ditemukan kasus siswa sekolah dasar yang salah dalam mengkomunikasikan konsep-konsep matematik secara tertulis. Misalnya kasus $2+3 \times 5=15=2+15$ $=17$. Apabila dilihat hasil akhirnya saja, mungkin jawaban dari soal tersebut benar, tetapi apabila kita melihatnya secara utuh jawaban tersebut tidak benar, karena kalimat di atas tidak logis. Kasus-kasus seperti di atas banyak dan sering kita jumpai, baik pada siswa maupun pada gurunya ketika mengajar.

Pengelompokkan belajar umumnya dilakukan dengan anggota kelompok tetap. Jarang dilakukan pengelompokkan belajar dengan anggota kelompok yang berganti-ganti atau kelompok tidak tetap atau kelompok tidak permanen. Kelompok dengan anggota tidak permanen adalah kelompok belajar yang anggotanya berubah-ubah. Pengelompkan seperti ini memiliki karakteristik anggota yang dinamis, senang tantangan, supel, pengalaman anggota belajarnya 
relatif beragam sebagai akibat dari pergantian teman belajar. Sehingga diduga anggota dari kelompok belajar tidak permanen akan memiliki kemampuan penalaran dan komunikasi matematik lebih baik serta sikapnya terhadap matematika juga lebih positif.

Sebagaimana yang dikemukakan bahwa penelitian ini mengkaji tentang model pembelajaran matematika menggunakan pendekatan kontekstual dalam meningkatkan kemampuan penalaran, komunikasi matematik, dan sikap siswa terhadap pembelajaran matematika, maka atas dasar uraian di atas permasalahan penelitian ini dirumuskan ke dalam permasalah berikut.

1. Apakah ada perbedaan hasil belajar matematika siswa antara yang mendapat pembelajaran matematika kontekstual dengan pembelajaran matematika biasa ?

2. Apakah ada perbedaan hasil belajar antara siswa yang mendapat pembelajaran matematika kontekstual kelompok permanen dengan pembelajaran matematika kontekstual kelompok tidak permanen ?

Lebih lanjut rumusan permasalahan di atas dirinci ke dalam pertanyaanpertanyaan penelitian berikut.

a. Apakah kemampuan penalaran, komunikasi matematik, dan sikap siswa yang mendapat pembelajaran matematika kontekstual kelompok tidak permanen (PMKKTP) lebih baik daripada kemampuan penalaran siswa yang mendapat pembelajaran matematika kontekstual kelompok permanen (PMKKP) menurut katagori sekolah?

b. Apakah kemampuan penalaran, komunikasi matematik, dan sikap siswa yang mendapat pembelajaran matematika kontekstual (PMK) lebih baik daripada kemampuan penalaran siswa yang mendapat pembelajaran matematika biasa (PMB) menurut katagori sekolah ?

c. Apakah ada interaksi dalam kemampuan penalaran, komunikasi matematik, dan sikap siswa antara model pembelajaran matematika kontekstual kelompok tidak permanen, pembelajaran matematika kontekstual kelompok permanen dan pembelajaran matematika biasa dengan katagori sekolah ? 
d. Apakah kemampuan penalaran, komunikasi matematik, dan sikap siswa yang mendapat pembelajaran matematika kontekstual (PMK) lebih baik daripada kemampuan penalaran siswa yang mendapat pembelajaran matematika biasa (PMB) dilihat dari keseluruhan ?

Penelitian ini difokuskan kepada pembelajaran di kelas yang memusatkan perhatian kepada peningkatan kemampuan penalaran dan komunikasi matematika siswa dalam pembelajaran matematika kontekstual melalui belajar kelompok. Tujuan umum studi ini adalah mendeskripsikan kemampuan penalaran, komunikasi matematik, dan sikap siswa melalui pembelajaran matematika kontekstual di sekolah dasar. Secara khusus tujuan penelitian ini dijabarkan seperti di bawah ini.

1. Untuk mengetahui apakah kemampuan penalaran, komunikasi matematik, dan sikap siswa yang mendapat pembelajaran matematika kontekstual kelompok tidak permanen (PMKKTP) lebih baik dari kemampuan penalaran siswa yang mendapat pembelajaran matematika kontekstual kelompok permanen (PMKKP) menurut katagori sekolah.

2. Untuk mengetahui apakah kemampuan penalaran, komunikasi matematik, dan sikap siswa yang mendapat pembelajaran matematika kontekstual (PMK) lebih baik dari kemampuan penalaran siswa yang mendapat pembelajaran matematika biasa (PMB) menurut katagori.

3. Untuk mengetahui ada atau tidak ada interaksi antara model pembelajaran dengan katagori sekolah terhadap kemampuan penalaran, komunikasi matematik, dan sikap siswa.

4. Untuk mengetahui apakah kemampuan penalaran, komunikasi matematik, dan sikap siswa yang mendapat pembelajaran matematika kontekstual (PMK) lebih baik dari kemampuan penalaran siswa yang mendapat pembelajaran matematika biasa (PMB) dilihat dari keseluruhan.

\section{B. Metode Penelitian}

Penelitian ini adalah penelitian kuasi eksperimen dengan dua kelas perlakuan, yaitu kelas dengan pembelajaran matematika kontekstual kelompok 
permanen dan pembelajaran matematika kontekstual kelompok tidak permanen. Kelas kontrolnya adalah kelas dengan pembelajaran matematika konvensional atau pembelajaran matematika biasa. Variabel bebas penelitian ini adalah pembelajaran matematika kontekstual yang terbagi ke dalam pembelajaran matematika kontekstual kelompok permanen (PMKKP) dan pembelajaran matematika kontekstual kelompok tidak permanen (PMKKTP). Sehingga disain penelitian yang dipilih adalah sebagai berikut.

$\begin{array}{lll}\mathrm{O} & \mathrm{X}_{1} & \mathrm{O} \\ \mathrm{O} & \mathrm{X}_{2} & \mathrm{O} \\ \mathrm{O} & & \mathrm{O}\end{array}$

Disain di atas memperlihatkan bahwa setiap kelompok memperoleh pretes (O), dan setelah memperoleh perlakuan setiap kelompok diukur dengan postes (O). Sedangkan $\mathrm{X}_{1}$ dan $\mathrm{X}_{2}$ masing-masing adalah perlakuan dengan pembelajaran matematika kontekstual kelompok permanen (PMKKP) dan pembelajaran matematika kontekstual kelompok tidak permanen (PMKKTP). Kelas kontrolnya adalah pembelajaran matematika biasa (PMB). Untuk melihat pengaruh model pembelajaran tersebut terhadap kemampuan penalaran, komunikasi, dan sikap siswa maka dalam penelitian ini dilibatkan faktor kategori sekolah sedang dan rendah. Adapun uji statistik yang digunakan adalah uji Anova.

\section{Analisis Data}

\section{Kemampuan Awal Siswa}

Tabel 1.

Skor Rerata Pretes Kemampuan Penalaran

\begin{tabular}{|c|c|c|c|c|c|}
\hline & \multicolumn{3}{|c|}{ Model Pembelajaran } & \multirow{2}{*}{$\begin{array}{c}\text { Rerata } \\
\text { Kategori }\end{array}$} \\
\hline & & PMKKP & PMKKTP & PMB & \\
\hline \multirow[b]{2}{*}{ Kategori } & Sedang & 17,77 & 17,63 & 17,43 & 17,61 \\
\hline & Rendah & 17,06 & 17,68 & 17,35 & 17,36 \\
\hline \multicolumn{2}{|c|}{ Rerata Kelompok } & 17,39 & 17,65 & 17,39 & \\
\hline
\end{tabular}

Skor ideal adalah 50

Hasil analisis statistik diperoleh bahwa kemampuan awal penalaran siswa di tiga model pembelajaran menurut kategori sekolah tidak berbeda secara signifikan. Dengan kata lain kemampuan awal penalaran siswa pada PMKKP, 
PMKKTP, dan PMB menurut kategori sekolah sedang dan rendah adalah homogen.

Tabel 2.

Skor Rerata Pretes Kemampuan Komunikasi Matematik

\begin{tabular}{|c|c|c|c|c|c|}
\cline { 3 - 5 } \multicolumn{2}{c|}{} & \multicolumn{3}{c|}{ Model Pembelajaran } & Rerata \\
\cline { 3 - 5 } \multicolumn{2}{c|}{} & PMKKP & PMKKTP & PMB & Kategori \\
\hline \multirow{3}{*}{ Kategori } & Sedang & 16,77 & 17,13 & 16,93 & 16,94 \\
\cline { 2 - 5 } & Rendah & 16,70 & 17,10 & 16,97 & 16,98 \\
\hline \multicolumn{2}{|c|}{ Rerata Kelompok } & 16,73 & 17,11 & 16,96 & \\
\hline
\end{tabular}

Skor ideal adalah 50

Hasil analisis statistik diperoleh bahwa kemampuan awal komunikasi matematik siswa di tiga model pembelajaran menurut kategori sekolah tidak berbeda secara signifikan. Dengan kata lain kemampuan awal komunikasi matematik siswa pada PMKKP, PMKKTP, dan PMB menurut kategori sekolah sedang dan rendah adalah homogen.

\section{Kemampuan Siswa Setelah Perlakuan}

Berikut adalah kemampuan penalaran, komunikasi matematik, dan sikap siswa setelah perlakuan. Kemampuan-kemampuan tersebut disajikan dalam tabel dan diagram berkut.

Tabel 3.

Skor Rerata Postes Kemampuan Penalaran

\begin{tabular}{|c|c|c|c|c|c|}
\hline & \multicolumn{3}{|c|}{ Model Pembelajaran } & \multirow{2}{*}{$\begin{array}{c}\text { Rerata } \\
\text { Kategori }\end{array}$} \\
\hline & & PMKKP & PMKKTP & PMB & \\
\hline \multirow[b]{2}{*}{ Kategori } & Sedang & 37,27 & 33,80 & 29,37 & 33,48 \\
\hline & Rendah & 32,48 & 30,87 & 25,42 & 29,59 \\
\hline \multicolumn{2}{|c|}{ Rerata Kelompok } & 35,42 & 32,32 & 27,36 & \\
\hline
\end{tabular}

Skor ideal adalah 50 


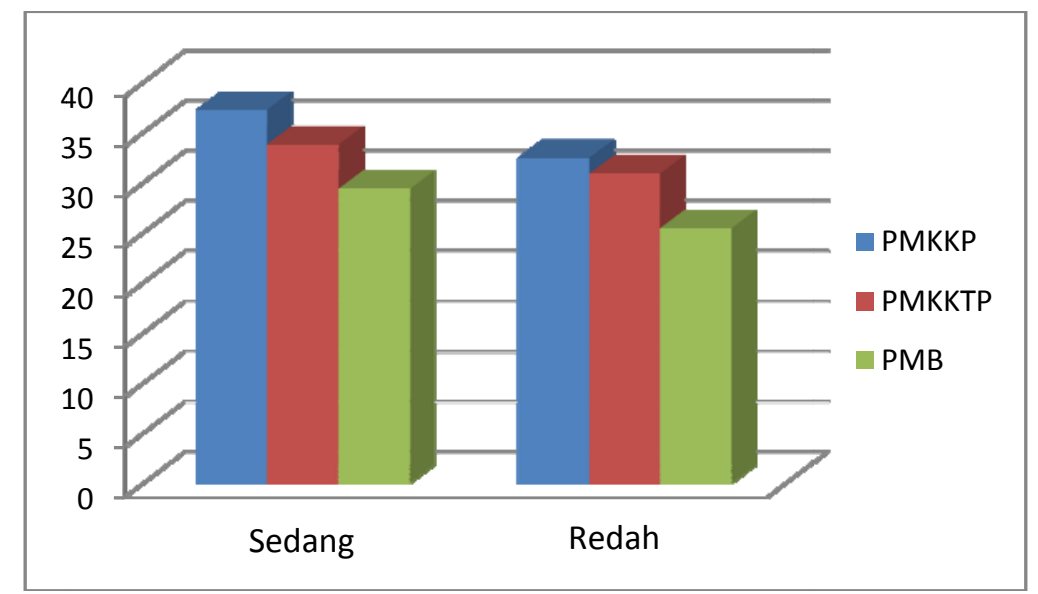

Gambar 1. Diagram Batang Kemampuan Penalaran

Tabel. 4

Skor Rerata Postes Kemampuan Komunikasi Matematik

\begin{tabular}{|c|c|c|c|c|c|}
\hline & \multicolumn{3}{|c|}{ Model Pembelajaran } & \multirow{2}{*}{$\begin{array}{c}\text { Rerata } \\
\text { Kategori }\end{array}$} \\
\hline & & PMKKP & PMKKTP & PMB & \\
\hline \multirow[b]{2}{*}{ Kategori } & Sedang & 37,47 & 34,77 & 25,57 & 32,60 \\
\hline & Rendah & 29,48 & 32,65 & 24,23 & 28,79 \\
\hline \multicolumn{2}{|c|}{ Rerata Kelompok } & 33,41 & 33,69 & 24,89 & \\
\hline
\end{tabular}

Skor ideal adalah 50

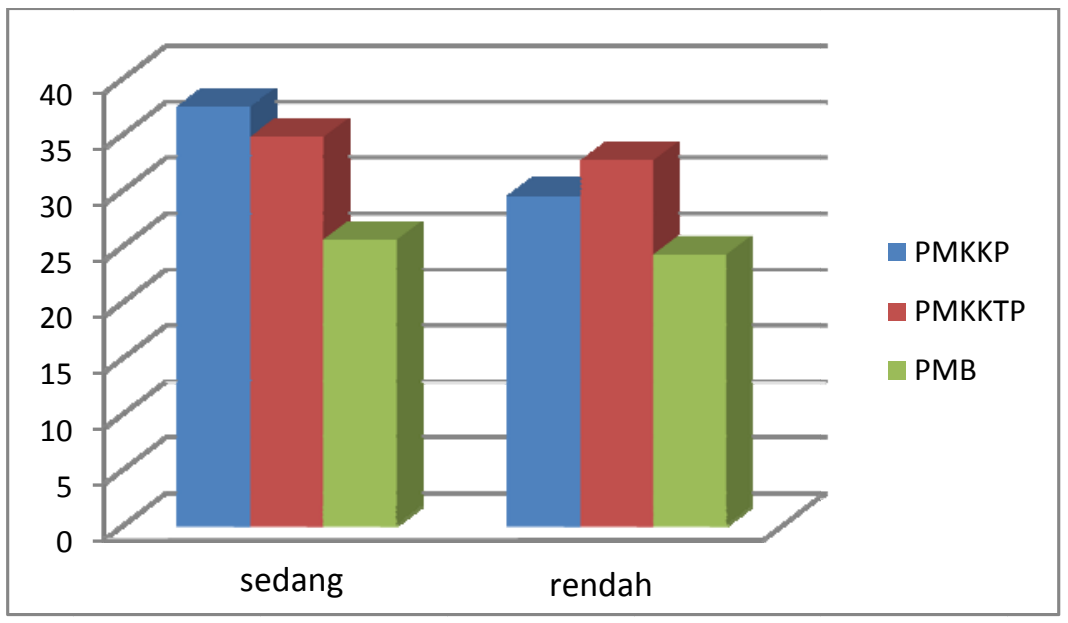

Gambar 2. Diagram Batang Kemampuan Komunikasi Matematik 
Tabel. 5

Skor Rerata Sikap Siswa

\begin{tabular}{|c|c|c|c|c|c|}
\hline & \multicolumn{4}{|c|}{ skor kerata sıkap siswa } \\
\hline & & \multirow[b]{2}{*}{ PMKKP } & \multirow[b]{2}{*}{ PMKKTP } & \multirow[b]{2}{*}{ PMB } & \multirow{2}{*}{$\begin{array}{l}\text { Rerata } \\
\text { Kategori }\end{array}$} \\
\hline & & & & & \\
\hline \multirow[b]{2}{*}{ Kategori } & Sedang & 57,50 & 56,81 & 39,55 & 51,29 \\
\hline & Rendah & 54,65 & 55,77 & 38,80 & 49,74 \\
\hline \multicolumn{2}{|c|}{ Rerata Kelompok } & 56,08 & 56,29 & 39,18 & \\
\hline
\end{tabular}

Skor ideal adalah 65

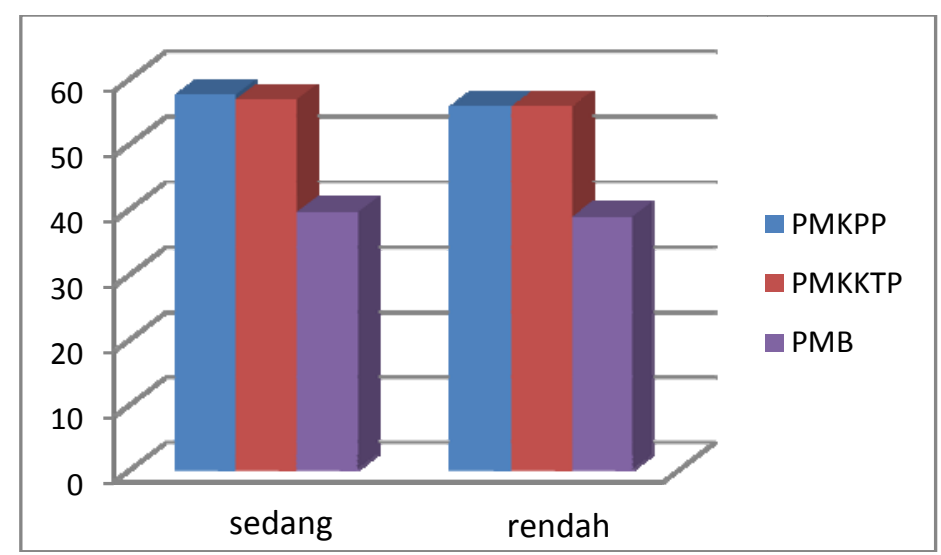

Gambar 3. Diagram Batang Sikap Siswa

2. Pengaruh Model Pembelajaran dan Kategori Sekolah Terhadap Kemampuan Siswa

a. Pengaruh Model Pembelajaran dan Katagori Sekolah Terhadap Penalaran

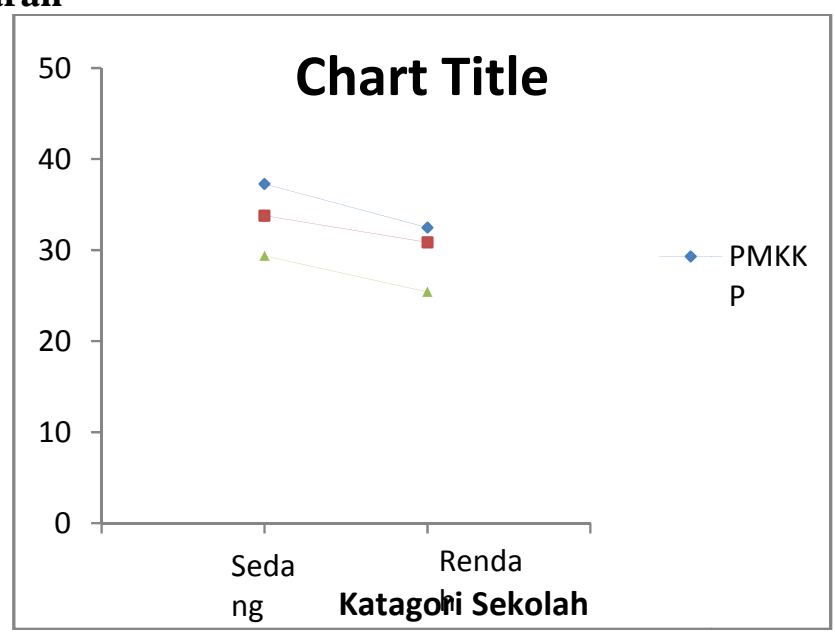


Gambar 4. Interaksi Antara Model Pembelajaran Dengan Kategori Sekolah Terhadap Penalaran

b. Pengaruh Model Pembelajaran dan Kategori Sekolah Terhadap Kemampuan Penalaran

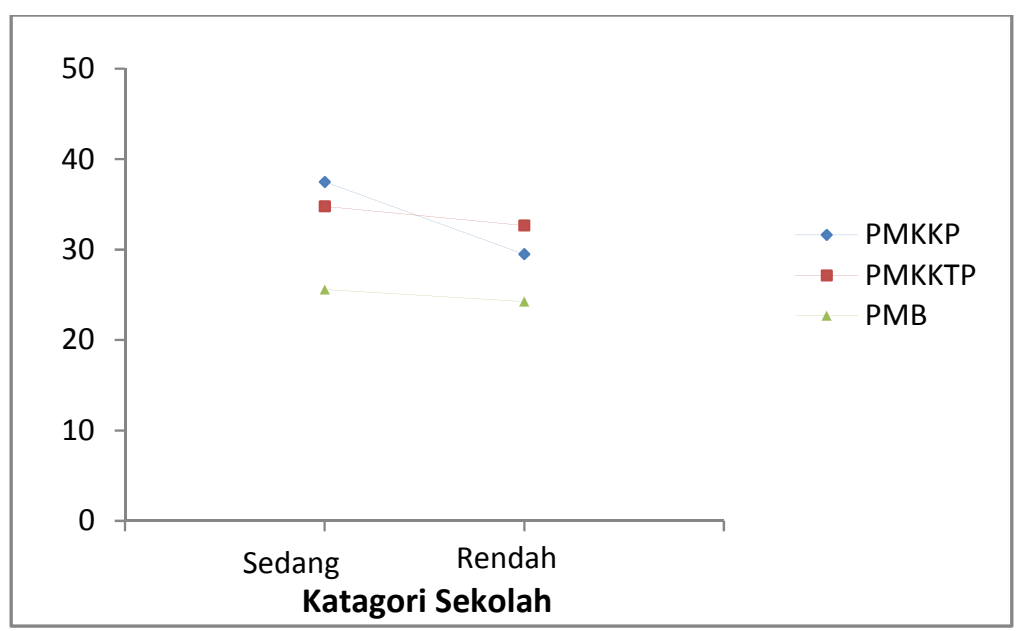

Gambar 5. Interaksi Antara Model Pembelajaran dengan Kategori Sekolah Terhadap Komunikasi Matematik

c. Pengaruh Model Pembelajaran dan Kategori Sekolah Terhadap Sikap Siswa

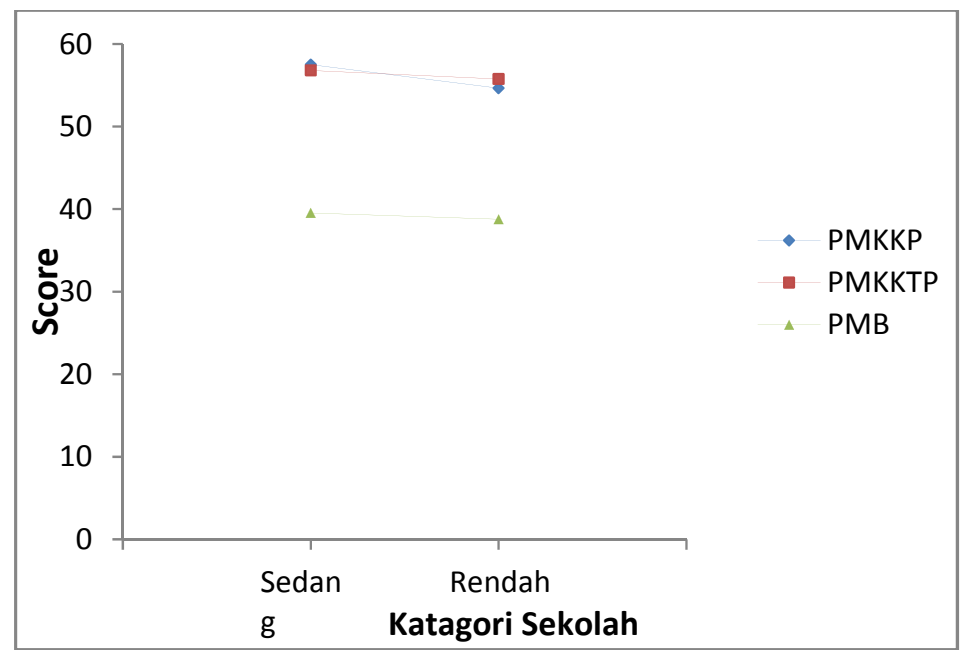

Gambar 6. Interaksi Antara Model Pembelajaran dengan Kategori Sekolah

Terhadap Sikap Siswa 


\section{Kesimpulan dan Rekomendasi}

Berdasarkan hasil penelitian yang telah dilakukan, diperoleh kesimpulan sebagai berikut.

1. Pada kategori sekolah sedang, kemampuan penalaran matematik siswa pada pembelajaran matematika kontekstual kelompok permanen tidak berbeda secara signifikan dengan kemampuan penalaran matematik siswa pada pembelajaran matematika kontekstual kelompok tidak permanen.

2. Pada kategori sekolah sedang, kemampuan penalaran matematik siswa pada pembelajaran matematika kontekstual secara signifikan lebih baik dibandingkan kemampuan penalaran matematik siswa pada pembelajaran matematika biasa.

3. Pada kategori sekolah rendah, kemampuan penalaran matematik siswa pada pembelajaran matematika kontekstual kelompok permanen tidak berbeda secara signifikan dibandingkan kemampuan penalaran matematik siswa pada pembelajaran matematika kontekstual kelompok tidak permanen.

4. Pada kategori sekolah rendah, kemampuan penalaran matematik siswa pada pembelajaran matematika kontekstual secara signifikan lebih baik dibandingkan kemampuan penalaran matematik siswa pada pembelajaran matematika biasa.

5. Pada taraf kepercayaan 0,05 tidak terjadi interaksi secara signifikan antara model pembelajaran dengan kategori sekolah terhadap kemampuan penalaran.

6. Secara keseluruhan kemampuan penalaran matematik siswa pada pembelajaran matematika kontekstual berbeda secara signifikan dibandingkan kemampuan penalaran matematik siswa pada pembelajaran matematika biasa.

7. Pada kategori sekolah sedang, kemampuan komunikasi matematik siswa pada pembelajaran matematika kontekstual kelompok permanen tidak berbeda secara signifikan dibandingkan kemampuan komunikasi matematik siswa pada pembelajaran matematika kontekstual kelompok tidak permanen.

8. Pada kategori sekolah sedang, kemampuan komunikasi matematik siswa pada pembelajaran matematika kontekstual secara signifikan lebih baik 
dibandingkan kemampuan komunikasi matematik siswa pada pembelajaran matematika biasa.

9. Pada kategori sekolah rendah, kemampuan komunikasi matematik siswa pada pembelajaran matematika kontekstual kelompok permanen tidak berbeda secara signifikan dibandingkan kemampuan komunikasi matematik siswa pada pembelajaran matematika kontekstual kelompok tidak permanen.

10. Pada kategori sekolah rendah, kemampuan komunikasi matematik siswa pada pembelajaran matematika kontekstual secara signifikan lebih baik dibandingkan kemampuan komunikasi matematik siswa pada pembelajaran matematika biasa.

11. Pada taraf kepercayaan 0,05 terjadi interaksi secara signifikan antara model pembelajaran dengan kategori sekolah terhadap kemampuan komunikasi matematik.

12. Secara keseluruhan kemampuan komunikasi matematik siswa pada pembelajaran matematika kontekstual berbeda secara signifikan dibandingkan kemampuan komunikasi matematik siswa pada pembelajaran matematika biasa.

13. Pada kategori sekolah sedang, sikap siswa pada pembelajaran matematika kontekstual kelompok permanen secara signifikan tidak berbeda dibandingkan sikap siswa pada pembelajaran matematika kontekstual kelompok tidak permanen.

14. Pada kategori sekolah sedang, sikap siswa pada pembelajaran matematika kontekstual secara signifikan lebih baik dibandingkan sikap siswa pada pembelajaran matematika biasa.

15. Pada kategori sekolah rendah, sikap siswa pada pembelajaran matematika kontekstual kelompok permanen secara signifikan tidak berbeda dibandingkan sikap siswa pada pembelajaran matematika kontekstual kelompok tidak permanen.

16. Pada kategori sekolah rendah, sikap siswa pada pembelajaran matematika kontekstual secara signifikan lebih baik dibandingkan sikap siswa pada pembelajaran matematika biasa. 
17. Pada taraf kepercayaan 0,05 terjadi interaksi secara signifikan antara model pembelajaran dengan kategori sekolah terhadap sikap siswa.

18. Secara keseluruhan sikap siswa pada pembelajaran matematika kontekstual lebih baik dibandingkan sikap siswa pada pembelajaran matematika biasa.

Rekomendasi atas hasil penelitian ini adalah sebagai berikut.

1. Mengingat hasil penelitian menunjukkan bahwa, kemampuan penalaran matematik siswa pada pembelajaran matematika kontekstual kelompok permanen dan pembelajaran matematika kontekstual kelompok tidak permanen secara signifikan lebih baik dibandingkan kemampuan penalaran matematik siswa pada pembelajaran matematika biasa, maka hendaknya pembelajaran matematika menggunakan pendekatan kontekstual dengan pengelompokan menjadi alternatif pilihan semua pihak ketika mengajarkan matematika di sekolah dasar.

2. Mengingat hasil penelitian menunjukkan bahwa, kemampuan komunikasi matematik siswa pada pembelajaran matematika kontekstual baik pada kelompok permanen maupun pada kelompok tidak permanen secara signifikan lebih baik dibandingkan kemampuan komunikasi matematik siswa pada pembelajaran matematika biasa, maka hendaknya pembelajaran matematika menggunakan pendekatan kontekstual dengan pengelompokan menjadi alternatif pilihan semua pihak ketika mengajarkan matematika di sekolah dasar.

3. Hasil penelitian juga menunjukkan bahwa sikap siswa terhadap matematika pada pembelajaran matematika kontekstual kelompok permanen dan pembelajaran matematika kontekstual kelompok tidak permanen lebih baik dibandingkan sikap siswa pada pembelajaran matematika biasa, maka hendaknya pembelajaran matematika menggunakan pendekatan kontekstual dengan pengelompokan menjadi perhatian dan alternatif untuk dilakukan saat pembelajaran matematika di sekolah dasar.

4. Walaupun dalam taraf kepercayaan 0,05 bahwa pada kedua katagori sekolah sedang maupun rendah kemampuan penalaran siswa menunjukkan tidak berbeda secara signifikan pada kedua kelompok namun kemampuan penalaran siswa pada kelompok permanen lebih baik dari kemampuan siswa pada 
kelompok tidak permanen. Hal ini disebabkan diantaranya kebiasaan yang cenderung memilih teman belajar yang tetap lebih diminati siswa. Keadaan ini bertolak belakang dengan tantangan kehidupan di era global yang menuntut semua orang untuk bersikap dinamis seperti dapat hidup dan bergaul dengan siapa saja. Oleh karenanya kultur belajar di kelas harus banyak berubah, diantaranya penggunaan setting belajar kelompok dengan pasangan yang berubah-ubah hendaknya lebih banyak dilakukan.

5. Hendaknya dilakukan penelitian lanjut mengenai bagaimana kemampuan penalaran dan komunikasi matematik siswa sekolah dasar yang belajarnya menggunakan pendekatan matematika kontekstual kelompok permanen dan kelompok tidak permanen dibandingkan dengan model pengelompokan model Student Team Achievement Divison dan model Jigsaw yang melibatkan katagori siswa pandai, sedang dan kurang.

\section{DAFTAR PUSTAKA}

Confrey, J. (1994). A Theory of Intellectual Development (Part. I). The Learning of Mathematics, 14 (3), XiV, 2-8.

Fauzan, Ahmad (2002). Applying Realistic Mathematics Education in Teaching Geometry in Indonesia Primary Schools. Thesis. Enschede: University of Twente.

Marpaung, J. (2001). Laporan Pilot Project RME, Indonesia.

Mullis, I. V. S., Martin, M.O., Gonzales, E.J., Gregory, K.D., Garden, R.A., O'Connor, K.M., Chrostowski, S.J., dan Smith, T.A. (2000). TIMSS 1999: International Mathematics Report. Boston: The International Study Center, Boston College, Lynch School of Education.

NCTM (2000). Curriculum and Evaluation Standards for School Mathematics. Reston, VA: Author.

Piaget, J. (1980). Adaptation and Intelligence: Organic Selection and Phenocopy (S. Eames, Trans.) Chicago: University of Chicago Press.

Sembiring, R. K. (2006). Bulatan Pecahan dan Pizza Mini. PMRI Tidak Sekadar Belajar Matematika. (h. 3). Bandung: IP-PMRI, FMIPA, ITB.

Suryadi, D. (2008). Metapedadidaktik Dalam Pembelajaran Matematika: Suatu Strategi Pengembangan Diri Menuju Guru Matematika Profesional. Pidato Pengukuhan. Bandung: UPI.

Van den Heuvel-Panhuizen (1998). Realistic Mathematics Education Work. Available: http//www.fi.uu.nl

Vygotsky, L. S. (1987). Collected Works (Volume I). New York: Plenum.

Wahyudin (2005). Matematika, Pendidikan Matematika dan Kurikulum Matematika. Pidato Pengukuhan Guru Besar Tetap FPMIPA. UPI. 
Zulkardi (2001). Realistic Mathematics Education (RME): Teori, Contoh Pembelajaran dan Taman Belajar di Internet. Makalah. Bandung.

\section{BIODATA PENULIS}

Husen Windayana adalah dosen pada Universitas Pendidikan Indonesia dpk. UPI Kampus Cibiru Bandung. Selain sebagai tenaga edukatif, penulis juga adalah Wakil Kepala SD Laboratorium UPI Kampus Cibiru. Penulis menyelesaikan pendidikan pada jenjang doktor (S-3) Pendidikan Matematika Sekolah Pascasarjana Universitas Pendidikan Indonesia. 